Wilson, E.O. 2003

\title{
Pheidole in the New World: A Dominant, Hyperdiverse Ant Genus
}

Harvard University Press, Cambridge, 794 p + CD ROM. ISBN 0-674-00293. Price US\$110.00.

Review with a special emphasis on the Brazilian Pheidole ant fauna and megadiversity distribution in American countries

Completing his academic career the way he began, one of the most outstanding scientists of this century, Edward O. Wilson, published his formidable monographic revision of the New World Pheidole. Though formally retired since 1997, Wilson continues to labor as Emeritus Pellegrino University Research Professor of the Museum of Comparative Zoology of Harvard University. Dr. Wilson is well known to biologists and ecologists as the author of Sociobiology, Biophilia, Island Biogeography, among others. Wilson, in spite of this breadth of vision and synthesis, is the foremost living myrmecologist. To those who know him, the sheer passion that he shares for ants he extends to all other living beings, and it is this commitment which has highlighted his Biodiversity advocacy, and he is now one of its principle spokesmen. His monumental revisionary monograph of Pheidole follows last year's publication of The Future of Life (Wilson 2002), the most accessible and impassioned of his appeals to humans to take heed of the millions of other species that make the planet habitable.

Pheidole in the New World is Wilson's masterful revision of the species rich ant genus that he has scrutinized for 16 years, as known to all friends and myrmecologists. To deal with the enormous number of species, Wilson defines the term "Hyperdiversity" to describe the species-richness of Pheidole. Hyperdiversity is employed by Wilson to discuss "when a genus or family ... contains exceptionally large number of species with reference to plant and animal diversity as a whole." The large number of species is to be expected as Pheidole is the dominant taxon of New World ant ground ant assemblages (Fowler 1994), but some species are also arboreal and others have symbiotic relationships with myrmecophytes. Indeed, Pheidole is now the most species-diverse group of New World organisms after beetles (Chrysomelidae and Curculionidae). Placed in another light, Levi (2002), Wilson's colleague at the Museum of Comparative Zoology, estimates 1500 species of araenid spiders divided into 65 genera, 47 in Brazil, as occurring in the New World and these data show how hyperdiverse is the genus Pheidole.

The origin of these omnipresent faunal elements is still unclear. Pheidole has a world-wide distribution, although it is apparently dominant in the New World (Wilson 1976, Fowler 1994). The oldest fossil is from Oligocene shales of North America (Carpenter 1930), and is not common in the Dominician ambers (Baroni Urbani 1995). $2 \mathrm{~N}$ chromosome numbers of the studied species range in the neighborhood of 20, although an Indian species has a diploid number of 42 , not allowing for a clear interpretation. Old World diversification is however much lower than that found in the New World. Sister groups are presently interpreted as being Aphaenogaster, or the Indonesian Chimaeridris. Thus, much more research is needed to clarify the origin of this highly successful genus.

Wilson recognizes 624 Pheidole species in the Western Hemisphere. However, he notes that "undescribed species ... were still pouring in to the Harvard Collection as (this) monograph went to press" suggesting that 
many more species undoubtedly exist. This monumental binary key revision was in part supported by the world's taxonomists, which provided type specimens, the oldest dating from 1826. Wilson's research depended upon local collaborators who shipped him samples from collections throughout the United States, Latin America, and Europe, resulting in 337 new species. But, how does one organize such a monumental venture? Wilson began by dividing the taxa into 19 species groups, 2 of which are of Old World origin (megacephala and teneriffana both from Africa) but represented in the New World. One species group includes social parasitic forms, most of which are from Argentina and should grow as more myrmecological research continues in the New World.

Pheidole is spread through 35 New World countries, but the number of species, as well as the relative percentage of all species, varies greatly (Table 1). How does Brazil fit into the distribution of New World Pheidole? Is the mega-diversity of Brazil (Mittermeier and Werner 1990) also found in this highly speciose group? Indeed, the documented Brazilian Pheidole fauna represents $24.3 \%$ of its total diversity (152 species), followed by Mexico 18.6\% (116 species), Costa Rica 18.1\% (113 species), Colombia 15.2\% (95 species), Peru $12.5 \%$ (78 species) and the USA $12.2 \%$ (76 species) (Fig. 1). These values, however, only consider the absolute number of species for each country. Furthermore, the superficial area and the collecting effort varies greatly among countries. In order to minimize differences in the number of species per area of any country, we created an index to estimate the relative megadiversity of species of New World Pheidole, by dividing the total number of recorded species per country by the number of $10^{\circ}$ latitudinal bands of each country from $50^{\circ} \mathrm{N}$ to $50^{\circ} \mathrm{S}$. The highest relative megadiversity of species of Pheidole was found in Costa Rica, followed by Panama, Peru, Mexico, Colombia, Brazil, Ecuador, EUA, Trinidad, and Guatemala independently of their surface area (Fig. 2, Table 1). These data clearly show the high collecting effort in Costa Rica and Panama, two countries well studied by Wilson. Brazil's sixth position indicates that this country may exhibit a large Pheidole diversity, depending on increased collecting effort.

In Brazil, of the 19 species groups of Pheidole recognized by Wilson, only four are not present. The species groups crassicornis, granulata and pilifera are almost exclusively Nearctic. Additionally, the species group teneriffana, which is native to North Africa, has turned up in disturbed habitats in Cuba, Peru and California. Of the 15 species groups of Pheidole found in Brazil, tristis, diligens, fallax and flavens are, respectively, the most speciose and encompass $84 \%$ of the fauna. These species groups also represent the highest number of New World species, with flavens being the most species rich, followed by tristis, fallax and diligens (Fig. 3).

Of the 152 Brazilian species of Pheidole, $45.4 \%$ are apparently endemic to Brazil. Of these, $71 \%$ are known only from type localities, suggesting a broader geographic distribution, due to lack of systematic collections, or conversely restricted distributions which could lead to their rapid extinction without ever knowing their natural history. Of the total documented Brazilian fauna, 42.1\% have unknown biologies, or in another words, $65.2 \%$ of the Brazilian species are endemic and with unknown biologies (Table 2), suggesting a formidable amount of natural history still ahead, as well as the probable discovery of more species. In spite of this fact, no Pheidole appear in the Red List of Threatened Species for Brazil (MMA 2003), which surprisingly has only three ant species listed.

Wilson graciously recognized many prominent myrmecologists who have worked largely solitarily in Latin America, by naming species after them, including the masters W.L. Brown and $\mathrm{N}$. Kusnezov, and the present generation of myrmecologists J. Trager, W. MacKay, J. Lattke, C.R.F. Brandão, P. Oliveira, and H.G. Fowler. Wilson recognized the importance of the contributions in support of tropical conservation by Harrison Ford, Peter A. Seligmann and Sal Roush. Indeed, Wilson dedicated the 
book to his deceased mentor, W.L. Brown, who began the revision of this genus with Wilson more than 20 years ago (Brown 1981).

Wilson meticulously illustrated by hand all species, and showed another innovation (Fig. 4). Wilson introduced anatomical markers which highlight keyed taxonomic characters and should greatly assist new myrmecologists, as well as more experienced ones by making explicit identifying traits.

A CD accompanies the printed book. The CD micrographically illustrates the species and should facilitate production of local and regional faunal keys. Combined with work underway at the Museum of Comparative Zoology and elsewhere, this additional innovation assures that such painstaking research will henceforth be refined and accelerated using digital imaging and genomics techniques, and then promptly disseminated to users worldwide by the Internet. In scholarly terms, it bridges the established science of biological systematics and its imminent future. However, the CD contains a mistake concerning the total number of Pheidole species in Brazil. Instead of 150 species presented in the CD list, we have detected that the book shows 152 species for Brazil, including P. laevinota (diligens group) and $P$. nitidicollis (flavens group).

\section{ACKNOWLEDGMENTS}

The authors are grateful to Cynthia P.A. Prado for the valuable suggestions on the manuscript and Thiago S. de Azevedo for the help with the figures.

\section{REFERENCES}

Baroni Urbani, C. 1995. Invasion and extinction in the West Indian ant fauna revisited: the example of Pheidole (Amber Collection Stutgart Hymenoptera: Formicidae, VII: Myrmicinae, partim). Stutg. Beitr. Naturkd. Ser. B. (Geol. Palaontol.) 62: 1-10.

Brown, W.L. Jr. 1981. Preliminary contributions toward a revision of the ant genus Pheidole (Hymenoptera: Formicidae), Part I. J. Kansas Entomol. Soc. 54: 523-530.

Carpenter, F.M. 1930. The fossil ants of North America. Bull. Mus. Comp. Zool. 70: 1-66.

Fowler, H.G. 1994. Relative representation of Pheidole (Hymenoptera: Formicidae) in local ground ant assemblages of the Americas. An. Biol. 19: 29-37.

Levi, H.W. 2002. Keys to the genera of araneid orbweavers (Araneae, Araneidae) of the Americas. J. Arachnol. 30: 527-562.

Ministério do Meio Ambiente, IBAMA, Brazil. 2003. Lista de espécies ameaçadas de extinção.

Mittermeier, R.A. \& T.B. Werner. 1990. Wealth of plants and animals unites 'megadiversity' countries. Tropicus 4: 4-5.

Pauwels, G. J. 1997. Atlas geográfico melhoramentos. Melhoramentos, São Paulo. 80 p.

Wilson, E.O. 1976. Which are the most prevalent ant genera? Stud. Entomol. 19: 187-200.

Wilson, E.O. 2002. The Future of Life. Harvard University, Cambridge.

\footnotetext{
F.J. Zara ${ }^{1} \&$ H.G. Fowler ${ }^{2}$

1 UNESP, Campus do Litoral Paulista - Unidade de São Vicente, CEP 11330-900, São Vicente, SP, Brazil; fjzara@csv. unesp.br

2 Depto de Ecologia UNESP, Rio Claro - C. P. 199, CEP 13506-900, Rio Claro, SP, Brazil; hgfowler@rc.unesp.br
} 
TABLE 1

Statistics of species richness and country characteristics used in our analysis

$\begin{array}{ccccc}\text { Species } & \begin{array}{c}\text { Number of latitude bands } \\ \text { of } 10^{\circ} \text { covering each } \\ \text { country }\end{array} & \text { Country } & \text { Relative } \\ & \text { richness } & \text { Countrea }\left(\mathrm{Km}^{2}\right)^{*} & \begin{array}{c}\text { megadiversity Index } \\ \text { Species/latitude } 10^{\circ}\end{array}\end{array}$

\begin{tabular}{|c|c|c|c|c|}
\hline Argentina & 59 & 4 & 2.766 .889 & 14.75 \\
\hline Brazil & 152 & 5 & 8.511 .965 & 30.6 \\
\hline Uruguay & 4 & 1 & 186.925 & 4 \\
\hline Chile & 1 & 5 & 751.625 & 0.2 \\
\hline Paraguay & 9 & 2 & 406.750 & 4.5 \\
\hline Bolivia & 34 & 2 & 1.098 .575 & 17 \\
\hline Peru & 78 & 2 & 1.285 .215 & 39 \\
\hline Ecuador & 53 & 2 & 461.475 & 26.5 \\
\hline Colombia & 95 & 3 & 1.138 .915 & 31.7 \\
\hline Venezuela & 31 & 2 & 912.045 & 15.5 \\
\hline French Guiana & 7 & 1 & 91.000 & 7 \\
\hline Suriname & 8 & 1 & 163.820 & 8 \\
\hline Guyana & 13 & 1 & 214.970 & 13 \\
\hline Trinidad & 23 & 1 & 5.130 & 23 \\
\hline Curaçao (Dutch West Indies) & 1 & 1 & 993 & 1 \\
\hline Panamá & 46 & 1 & 78.515 & 46 \\
\hline Costa Rica & 113 & 2 & 50.900 & 56.5 \\
\hline Nicaragua & 11 & 1 & 148.000 & 11 \\
\hline Honduras & 19 & 1 & 112.085 & 19 \\
\hline El Salvador & 15 & 1 & 21.395 & 15 \\
\hline Guatemala & 20 & 1 & 108.890 & 20 \\
\hline Belize & 4 & 1 & 22.965 & 4 \\
\hline Bermudas & 1 & 1 & 54 & 1 \\
\hline Cuba & 12 & 2 & 114.525 & 6 \\
\hline Jamaica & 7 & 1 & 11.425 & 7 \\
\hline Haití & 4 & 1 & 27.750 & 4 \\
\hline Domenican Republic & 7 & 1 & 48.440 & 7 \\
\hline Dominica & 10 & 1 & 751 & 10 \\
\hline Puerto Rico & 8 & 1 & 8.960 & 8 \\
\hline St. Kitts and Nevis & 1 & 1 & 262 & 1 \\
\hline Bahamas & 4 & 1 & 13.865 & 4 \\
\hline $\begin{array}{l}\text { St. Vincent and } \\
\text { The Grenadines }\end{array}$ & 7 & 1 & 389 & 7 \\
\hline Grenada & 4 & 1 & 345 & 4 \\
\hline USA & 76 & 3 & 9.363 .130 & 25.3 \\
\hline Mexico & 116 & 3 & 1.972 .545 & 38.7 \\
\hline
\end{tabular}

(*) from Pauwels (1997) 
TABLE 2

Synoptic listing of what is known of the biologies and distributions of recorded Brazilian species of Pheidole

\begin{tabular}{|c|c|c|c|c|c|c|c|}
\hline Group & Species & $\begin{array}{l}\text { Known } \\
\text { biology }\end{array}$ & $\begin{array}{c}\text { Registered } \\
\text { only in } \\
\text { Brazil }\end{array}$ & Group & Species & $\begin{array}{c}\text { Know } \\
\text { biology }\end{array}$ & $\begin{array}{c}\text { Registered } \\
\text { only in } \\
\text { Brazil }\end{array}$ \\
\hline \multirow[t]{4}{*}{ aberrans } & aberrans & Yes & No & flavens & flavens & Yes & No \\
\hline & cavifrons & Yes & No & & flavida & No & Yes \\
\hline & fracticeps & Yes & No & & goeldii & No & Yes \\
\hline & minensis & No & Yes & & guajirana & Yes & No \\
\hline \multirow[t]{3}{*}{ biconstricta } & biconstricta & Yes & No & & ligniocola & No & No \\
\hline & simplex & Yes & No & & lucaris & Yes & Yes \\
\hline & socrates & No & No & & minutula & Yes & No \\
\hline crassicornis & ausency & in & Brazil & & nana & No & Yes \\
\hline \multirow[t]{32}{*}{ diligens } & angusta & No & Yes & & nitella & Yes & No \\
\hline & blumenauensis & No & Yes & & nitidicollis & No & No \\
\hline & bruensi & Yes & No & & obtusopilosa & Yes & No \\
\hline & camptostela & No & Yes & & peltastes & No & Yes \\
\hline & cataractae & Yes & No & & pholeops & Yes & No \\
\hline & chrysops & Yes & No & & rudigenis & Yes & No \\
\hline & coffeicola & No & No & & schmalzi & No & No \\
\hline & cyrtostela & Yes & Yes & & sospes & Yes & No \\
\hline & diligens & Yes & No & & subreticulata & No & Yes \\
\hline & embolopyx & Yes & No & & tambopatae & Yes & No \\
\hline & fowleri & Yes & Yes & & termitobia & Yes & Yes \\
\hline & geraesensis & No & Yes & & tetrica & No & Yes \\
\hline & laevifrons & No & Yes & & victma & No & Yes \\
\hline & laevinota & Yes & No & gertrudae & capillata & Yes & No \\
\hline & laidlowi & No & No & & gertrudae & No & No \\
\hline & lancifer & Yes & No & & jeannei & Yes & Yes \\
\hline & lemur & No & Yes & granulata & ausency & in & Brazil \\
\hline & longiscapa & Yes & No & lamia & colobopsis & Yes & No \\
\hline & longiseta & Yes & No & megacephala & megacephala & Yes & No \\
\hline & oxyops & Yes & No & perpusilla & perpusilla & Yes & No \\
\hline & peregrina & Yes & Yes & pilifera & ausency & in & Brazil \\
\hline & perryorum & Yes & Yes & pucntatissima & meinerti & Yes & No \\
\hline & pubiventris & Yes & No & & rugiceps & Yes & No \\
\hline & radoszkowskii & Yes & No & scrobifera & mamore & Yes & No \\
\hline & reichenspergeri & No & Yes & tachigaliae & mendicula & Yes & No \\
\hline & rochai & No & Yes & & pedana & No & No \\
\hline & rufipilis & No & Yes & teneriffana & ausency & in & Brazil \\
\hline & sensitiva & Yes & No & transversostriata & scolioceps & Yes & No \\
\hline & strigosa & Yes & Yes & & transversostriata & Yes & No \\
\hline & triconstricta & Yes & No & tristis & alexeter & Yes & Yes \\
\hline & vafra & Yes & No & & allarmata & Yes & No \\
\hline & veletis & Yes & No & & alpinensis & No & Yes \\
\hline \multirow[t]{4}{*}{ distorta } & bufo & Yes & No & & ambigua & No & Yes \\
\hline & deima & No & Yes & & aper & No & Yes \\
\hline & dolon & Yes & No & & auropilosa & No & No \\
\hline & monstrosa & No & Yes & & avia & No & Yes \\
\hline \multirow[t]{7}{*}{ fallax } & aenescens & No & Yes & & bambusarum & Yes & No \\
\hline & alienata & No & Yes & & brevicona & No & Yes \\
\hline & araenoides & Yes & Yes & & brunnescens & No & Yes \\
\hline & arcifera & No & Yes & & bucculenta & Yes & Yes \\
\hline & cardinalis & Yes & Yes & & carapuna & Yes & No \\
\hline & claviscapa & Yes & No & & cephalica & Yes & No \\
\hline & cuevasi & Yes & No & & cramptoni & Yes & No \\
\hline \multirow[t]{5}{*}{ fallax } & cursor & Yes & No & Tristis & descolei & No & No \\
\hline & eidmanni & No & Yes & & dyctiota & Yes & Yes \\
\hline & gigas & Yes & Yes & & fabricator & Yes & No \\
\hline & impressa & No & Yes & & fera & No & Yes \\
\hline & jacutifera & No & Yes & & fimbriata & Yes & No \\
\hline
\end{tabular}


TABLE 2 (Coninued)

Synoptic listing of what is known of the biologies and distributions of recorded Brazilian species of Pheidole

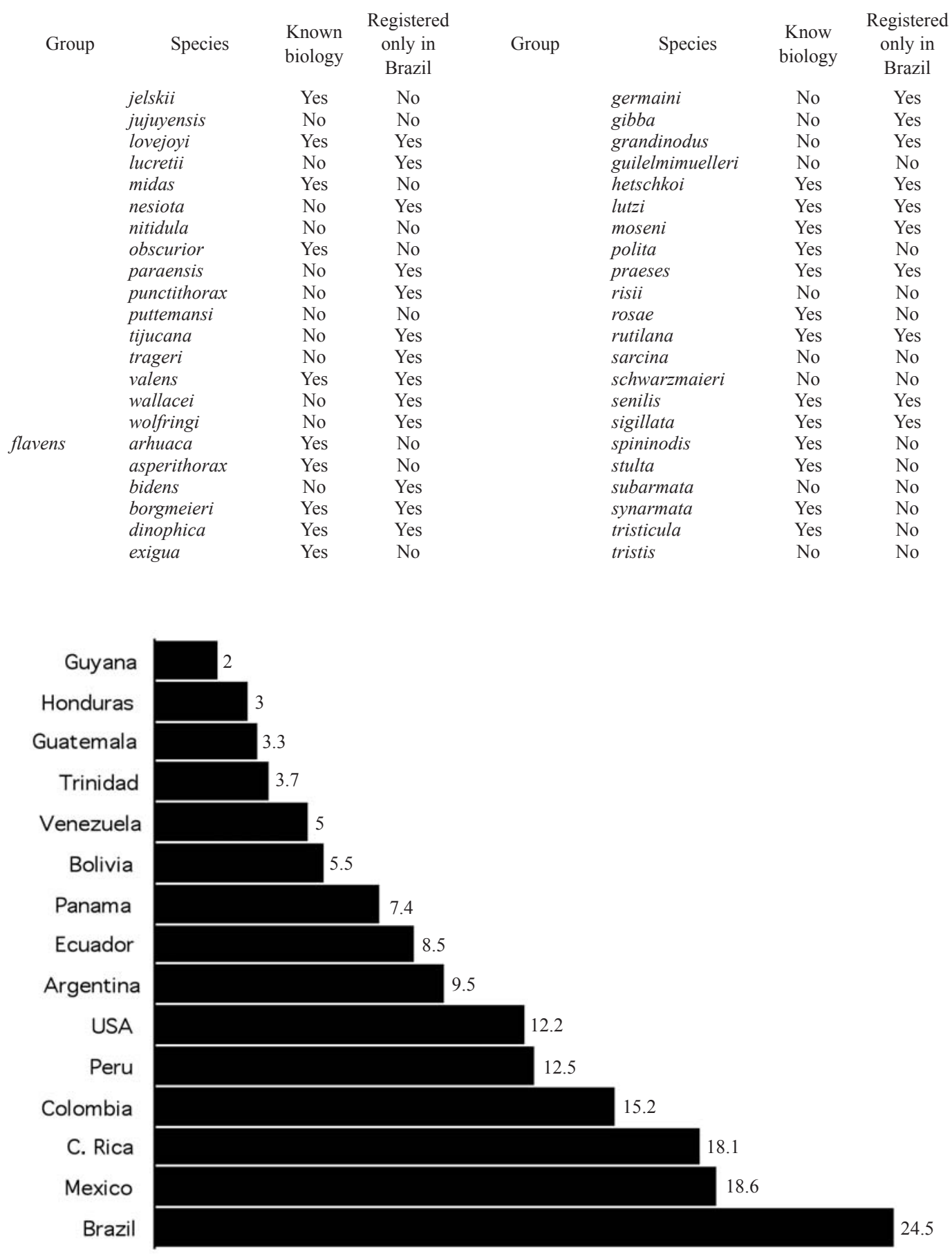

Fig. 1. The 15 New World countries with the largest number of species of Pheidole. Numbers above bars indicate the relative percentage of each country to the total number of species recognized by Wilson (2003). 


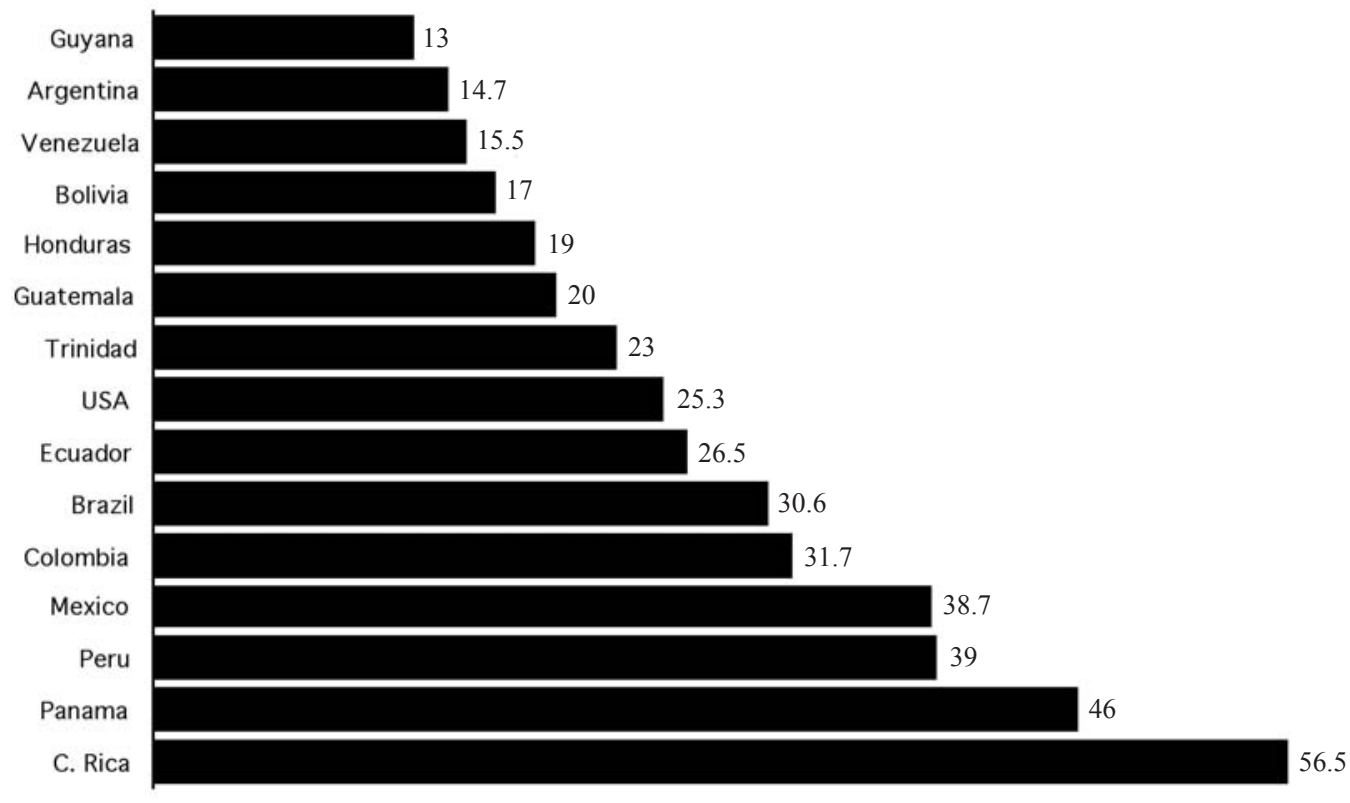

Fig. 2. Relative Pheidole megadiversity (number of species/number of $10^{\circ}$ latitudinal bands from $50^{\circ} \mathrm{N}$ to $50^{\circ} \mathrm{S}$ ) for the 15 most speciose countries of the New World.

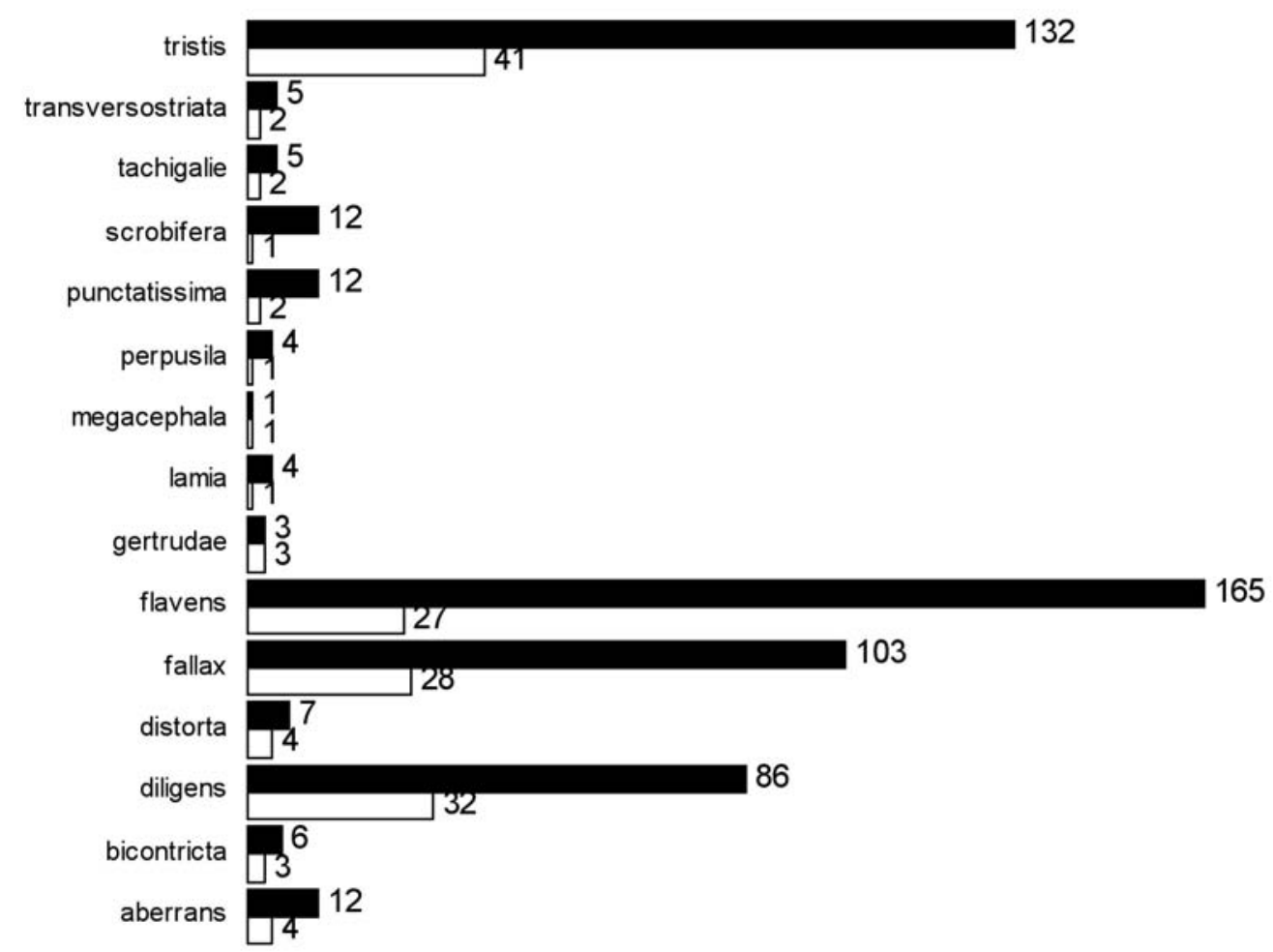

Fig. 3. Species richness of each 15 species groups of Pheidole found in Brazil (white bars) compared to the total New World species group (black bars). 


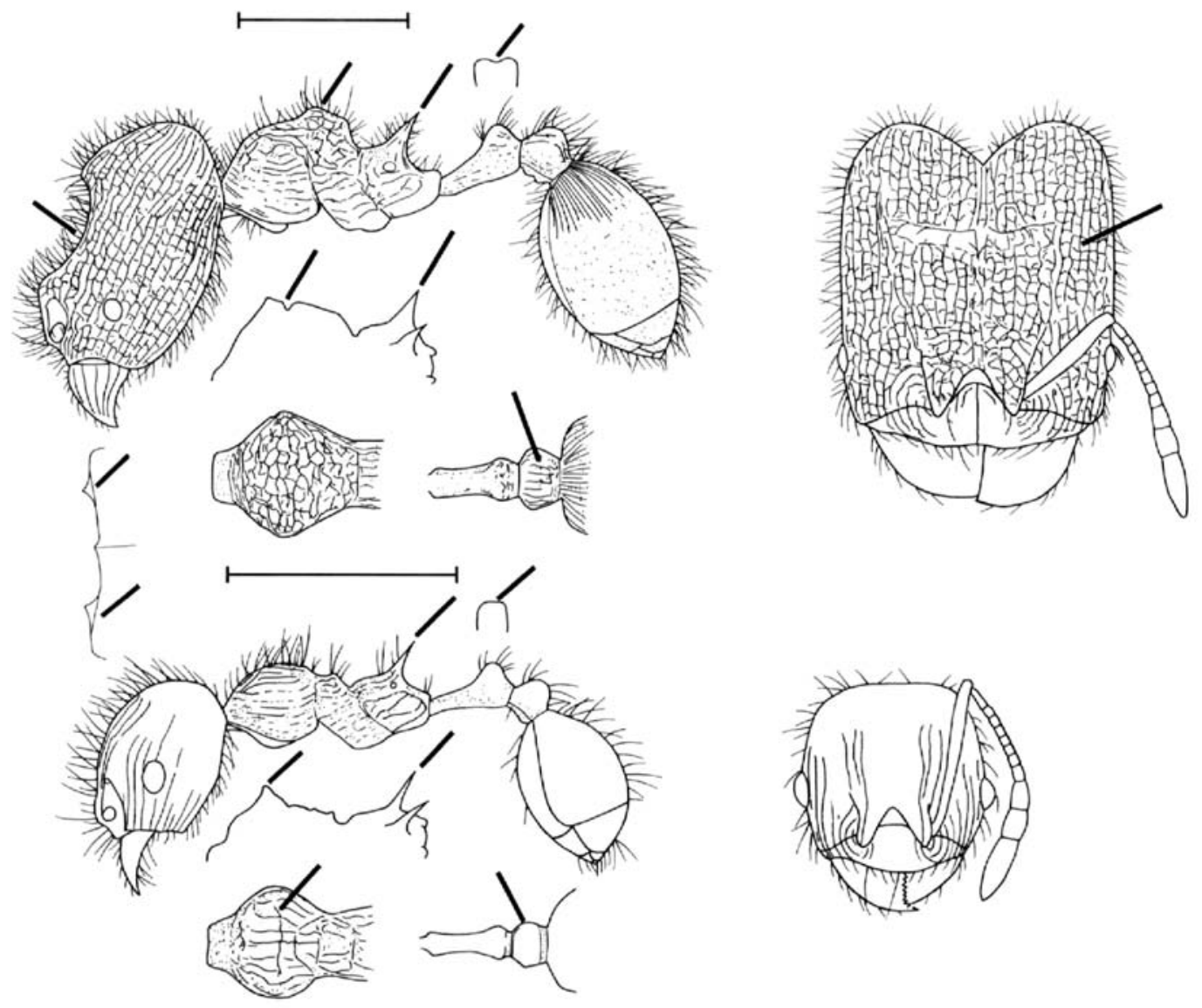

Fig. 4. Taxonomic markers used by Wilson to characterize anatomical features used in the identification keys. 